International Journal of Social Inquiry Cilt / Volume 12 Sayı / Issue 22019 ss./pp. 657-680

\title{
LEADERSHIP WITHOUT HIERARCHY AND AUTHORITY: LATERAL LEADERSHIP
}

\author{
R. Dilek KOÇAK* \\ 657 \\ Makale Geliş Tarihi-Received: 13.08.2019 \\ Makale Kabul Tarihi-Accepted: 30.11.2019 \\ DOI: $10.37093 /$ ijsi.659023

\begin{abstract}
Conventional leadership styles require hierarchical processes primarily characterized by the exertion of power. However, recent studies have indicated that lateral leadership, which substitutes a subordinating approach with insight, collaboration, coordination, and creativity with all stakeholders and especially with employees, can also achieve organizational goals. In this article, lateral leadership and thought system is discussed. Based on lateral thinking, it seeks contributions from all employees to make business more effective through creativity, innovation, and collaborative methods to meet the challenge of a globalized world. The basic mechanisms of lateral leadership are creating common understandings, changing power games, creating an atmosphere of trust, and eliminating hierarchical authority. In this context, the main findings of this article prepared within the framework of narrative review methodology; lateral leadership is a fairly new approach that is suited to changing working environments, leadership characteristics, organizational structures, and followers' qualifications. This leadership style is most appropriate for group studies, ad hoc meetings, or lateral-networking structures in organizations in which conventional leadership is ineffective or dysfunctional.
\end{abstract}

* Asst. Prof. Dr., University of Turkish Aeronautical Association, Faculty of Management, Ankara/Turkey. ORCID: https://orcid.org/0000-0002-3077-0706. dkocak@thk.edu.tr 
Keywords: Lateral Thinking, Lateral Leadership, Conventional Leadership, Vertical Thinking, Hierarchical Authority.

JEL Codes: M10, M12, L20. 


\section{HIIYERARŞİ VE OTORİTE OLMADAN LIDERLİK: LATERAL ${ }^{1}$ LIDERLIKK}

\section{ÖZ}

Geleneksel liderlik tarzları, öncelikle gücün kullanımı ile karakterize edilen hiyerarşik süreçleri gerektirir. Bununla birlikte, yakın tarihli çalışmalar, iç görü, iş birliği, eşgüdüm ve yaratıcilıkla tüm paydaşlarla ve özellikle çalışanlarla alt yönetim yaklaşımını yerine getiren lateral liderliğin de kurumsal hedeflere ulaşabileceğini göstermiştir. Bu makalede lateral liderlik ve dayandığ 1 düşünce sistemi ele alnnmaktadır. Lateral düşünme, tüm çalısanların küreselleşen bir dünyanın zorluğunu karşılamak için yaratıcllk, yenilikçilik ve işbirlikçi yöntemlerle işlerini daha etkin hale getirmelerine katkı sağlar. Lateral liderliğin temel mekanizmalar ortak anlayışlar oluşturmak, güç oyunların değiştirmek, güven atmosferi yaratmak ve hiyerarşik otoriteyi ortadan kaldırmaktır. Bu çerçevede geleneksel derleme metodolojisi çerçevesinde hazırlanan makalenin ana bulgusu; Lateral liderliğin değişen çalışma ortamları, liderlik özellikleri, organizasyonel yapılar ve takipçilerin niteliklerine uygun ve oldukça yeni bir yaklaşım olduğudur. Bu liderlik stili, geleneksel liderliğin etkisiz veya işlevsiz olduğu organizasyonlardaki grup çalışmaları, geçici toplantılar veya lateral ă̆ yapılar için en uygun olanıdır.

Anahtar Kelimeler: Lateral Düşünme, Lateral Liderlik, Geleneksel Liderlik, Dikey Düşünme, Hiyerarşik Otorite.

JEL Kodlari: M10, M12, L20.

1 "Lateral", kavramı Türkçe'de "Yan, yandan gelen, yanal" olarak karşılık bulmakla birlikte, yönetim ve organizasyon alanında "lateral Leadership" in Türkçe karşılığına rastlanmamıştır. "Lateral" in aynı zamanda Türkçe bazı bilim alanlarında (ör: tıp, diş hekimliği vb.) aynen kullanılması sebebi ile bu çalışmada da "Lateral" olarak yer verilmiştir. 


\begin{abstract}
INTRODUCTION
Scholars have vigorously discussed the role of leadership in society, politics, and business from various perspectives. As this topic extends across most social science fields, it has attracted keen interest, not only from business scholars, but also from psychologists, sociologists, philosophers, and others. Researchers in these fields acknowledge that leadership plays a crucial role in the success or failure of businesses, political organizations, and social movements. For example, if a firm fails to make a profit, its leaders - chief executive officer or general manager - face strong criticism. Because leadership and its style can enormously affect business activities, the interactions of business leaders are closely evaluated.

Leadership styles can differ from various perspectives as leaders have the authority to make others act. They have the power to influence the followers working for them. This power may have diverse sources of authority, such as legal, inherent or natural, tribal, eldership, or traditional, bureaucratic, or autocratic authority. Those power sources can create their own leadership styles, as we will see in following sections.

All the above-listed leadership styles require hierarchical processes mainly characterized by the exertion of power. However, recent studies have developed a new theoretical approach toward leadership style that replaces the subordinating approach with a focus on insight, collaboration, coordination, and creativity with all stakeholders, particularly employees, to achieve organizational goals. This lateral leadership avoids a hierarchical working atmosphere.

This study is prepared as narrative review paper. Narrative study is the critical literature research contained in books and articles. Digital and paper articles from narrative review literature play an important role in continuing learning as they give readers up-to-date information on a certain topic or subject (Shah, 2018). So, the purpose of this narrative review paper is to succinctly review lateral leadership and shed light on its evolution. For this purpose, the paper seeks the answers of the following questions:
\end{abstract}




\section{Leadership Without Hierarchy and Authority: Lateral Leadership}

- What is the theoretical background of leadership and leadership styles?

- What is the philosophical background of lateral leadership?

- How and why has lateral thinking transformed to lateral leadership?

- What are similarities and differences between conventional and lateral leadership?

- How is lateral leadership evolved in globalized?

From this perspective, after first defining leadership, the theoretical aspects of leadership and leadership styles will be examined to shed light on the intellectual debate and prepare the intellectual background to investigate lateral leadership. The paper then explains how it can be conceptualized and how it differs from other leadership styles in practice. The article concludes by assessing the concept and making some suggestions regarding lateral leadership.

The major finding of this paper is that lateral leadership, as a relatively new approach, is suitable for changing working environments, leadership characteristics, organizational structures, and followers' qualifications. This leadership style is most suitable for group studies, ad hoc meetings, or lateral-networking structures in organizations in which leadership conventional/traditional leadership is ineffective in digital age. It is thought that it will contribute to the literature since the subject is up-to-date and that there are few studies in the field.

\section{A BRIEF THEORETICAL REVIEW OF LEADERSHIP AND LEADERSHIP STYLES}

Before examining the theoretical aspects of leadership, the term should be clarified to understand the intellectual debate regarding lateral leadership.

Generally, leadership is a potential or capacity to influence others (Vroom, Jago, 2007: 17) in organizations such as groups or firms. Leadership has at least three dimensions: first, a capacity or potential to utilize achieving efficiency in a firm; second, a target to exert power 
over; third, positive outcomes from exerting its capacity or potential. Modern theories offer at least three conceptualizations. These include a process or relationship, an amalgamation of traits or personality features, specific deeds, or leadership talents. Leading theories explain it as a process that involves the capacity to influence individuals to accomplish goals (Wolinski, 2010).

Leadership inherently includes the power to influence workers to conduct business. That is, leadership has an authority that derives its power from various sources, such as legality, like prime ministers or ministers in a democracy. They exhibit democratic leadership because the source of their power is the legitimacy of their political activities. Other leadership styles have inherent or natural power, such as Max Weber's concept of charismatic leadership. Mustafa Kemal Ataturk would be an example of a charismatic leader. Leaders may also have tribal, eldership, or traditional authority, as in Afghanistan or certain Middle East countries. Eldership leadership does not require any external legality as traditions and customs in such countries inherently provide them with legality. Eldership and tradition influence group, tribal, or family members. On the other hand, autocratic leadership can use seized power to influence all followers. Hitler is the best example for such leadership. Power sources can create their own leadership styles, as we will see in the following sections.

In sum, leadership is the process of motivating people. Motivation is the major stimulus for leadership to accomplish its targets. However, leadership can also be described as a process rather than a property of an individual. "The consequence of the influence is collaboration in pursuit of a common goal" (Vroom, Jago, 2007: 18).

The style of leadership is determined by its capacity to exert power over others or its methods of influencing them. A high capacity involves coercive methods in which the power of authority is quite strong. Conversely, leadership influence may involve non-coercive methods or rely on moral values (Vroom, Jago, 2007: 17). Reliance on non-coercive methods requires collaboration and creativity with subordinates. This leadership style matches lateral leadership, as will be discussed in the following sections. 


\section{Leadership Without Hierarchy and Authority: Lateral Leadership}

The following paragraphs outline the major leadership theories that have been most discussed by scholars;

The oldest leadership theory, the Great Man theory, defines leadership as a heroic concept by asserting that great leaders have innate ability. The theory reflects $18^{\text {th }}$ century rationalist philosophical ideas by thinkers such as Carlyle, Nietzsche, and Galton. (Vroom, Jago, 2007: 18). It claims that great leaders are born with high-level abilities (Cherry, 2012). However, subsequent events demonstrated that this concept of leadership was ethically defective, as in the cases of Napoleon, Hitler, Mussolini, and Stalin. Their actions damaged the credibility of the theory and rendered it irrelevant (MacGregor, 2003; Khan et al., 2016). The ideal of a heroic, hierarchically oriented leader was replaced by a view prioritizing stewardship, ethical behavior, and collaboration through connecting with others (Dierendonck, Patterson, 2010: 5)

Of these later theories, trait theory argues that individuals have certain leadership-related potentials or traits. While the theory retains some essential features of the Great Man theory, it ignores assumptions about whether leadership traits are inherited or learned (Amanchukwu et al., 2015: 8). Instead, trait theories mostly outline a specific personality or behavioral features shared by successful leaders. Charisma, for example, was defined by max Weber as a fundamental component of trait leadership: "the greatest revolutionary force, capable of producing a new approach to leaders composed of almost magical supernatural, superhuman qualities and powers (Amanchukwu et al., 2015: 8; Cherry, 2012).

Contingency theories emphasize specific variables that might define which type of leadership is best appropriate for specific work circumstances. As no single leadership style is appropriate for all circumstances, success depends on several variables, such as leadership type, talents of followers, and situational features (Cherry, 2012).

Behavioral theories emphasize a leader's actions rather than intellectual qualities. That is, great leaders are made or brought up but not born. This entails that people can become successful leaders through training and observation. According to situational theory, "leaders select the best course of action according to circumstances. 
Thus, specific styles of leadership may be more appropriate for different types of decision-making" (Amanchukwu et al., 2015: 8). Participative theory suggests that ideal leadership requires considering others' views in decision-making systems. By including all people's views in the decision-making system, collaboration is increased, and the business is more successful.

Somewhat differently, transactional or management leadership first considers the rules, norms, and principles in an organization, and emphasizes supervision, group performance, and the interactions between leaders and followers. This kind of leadership can effectively rewards and punishments to attain goals. Finally, relationship or transformation theory highlights the established connection between managers and followers. Transformational leaders focus on motivation and inspire by acquiring a higher quality job (Cherry, 2012).

\subsection{Leadership Styles}

Leadership styles are the methods, attitudes, or approaches to motivating and persuading people, specifically followers, to accomplish the goals of an organization (Amanchukwu et al., 2015: 9). Therefore, leadership style can vary depending on the leadership role and its characteristics, organizational structure, organizational goals, and the characteristics of the interactions between the leadership and followers. Scholars have identified the following leadership styles.

Autocratic leadership focuses on utilizing extreme power to influence followers. Such a leaders' decisions and directives are precise. While the followers' views are rarely taken into consideration, the final decision is given by leader. It can be best applied in crises. Likewise, bureaucratic leadership is based on both leaders and followers obeying principles, rules, procedures, and norms. Such leadership is mostly suitable for work involving serious safety risks, financial issues, or routine tasks (Shaefer, 2005).

In contrast, charismatic leadership relies on the followers' confidence in the leader, and emphasizes motivation, eagerness, and inspiration to make followers work to accomplish goals. The danger is that extreme self-confidence may encourage leaders to believe they are infallible. 


\section{Leadership Without Hierarchy and Authority: Lateral Leadership}

On the other, hand, democratic leadership takes followers' views into consideration during decision making while retaining final authority.

Quite differently, transactional leadership requires that the followers obey the leader in return for obtaining work. Transactional leaders use appraisal measures to assess the followers' efforts and accomplishment (Amanchukwu et al., 2015: 9-10). Finally, servant leadership benefits organizations by engaging and developing staff through an attitude characterized by a sincere heart, mind and spirit. Jean Monnet, who made a critical contribution to the development of the European Union, is deemed the best example of this leadership style (Dierendonck, Patterson, 2010: 3).

Table 1. summarizes the major leadership theories and their relationships with leadership styles. Each leadership theory generally coincides with certain leadership styles with similar characteristics. However, as situational and contingency leadership theories can reflect wider characteristics, they can match several leadership styles depending on each situation and other variables. The Great Man Theory also matches than one leadership style as it has very specific features.

Table 1. Overlapping Leadership Theories (LT) and Leadership Styles

\begin{tabular}{|c|c|c|}
\hline Name of LT & Main proposal & Leadership styles matching LT \\
\hline Great Man LT & Great man as a born leader & $\begin{array}{l}\text { Autocratic leadership, Bureaucratic } \\
\text { leadership }\end{array}$ \\
\hline Trait LT & $\begin{array}{l}\text { Key leadership characteristics } \\
\text { either inherited or learned }\end{array}$ & Charismatic leadership \\
\hline Situational LT & $\begin{array}{l}\text { Leaders select the best course } \\
\text { of action based upon } \\
\text { situational conditions }\end{array}$ & $\begin{array}{l}\text { Any leadership style relevant, } \\
\text { depending on situational conditions }\end{array}$ \\
\hline Contingency LT & $\begin{array}{l}\text { Focus on variables defining the } \\
\text { most suitable type of } \\
\text { leadership }\end{array}$ & $\begin{array}{l}\text { Any leadership style relevant, } \\
\text { depending on situational conditions. }\end{array}$ \\
\hline Behavioral LT & Leaders made not born & Charismatic leadership \\
\hline Participative LT & $\begin{array}{l}\text { Ideal leadership achieved by } \\
\text { considering followers' views } \\
\text { in decision-making systems }\end{array}$ & $\begin{array}{l}\text { Democratic leadership, Charismatic } \\
\text { leadership, Servant Leadership }\end{array}$ \\
\hline $\begin{array}{l}\text { Transactional or } \\
\text { Management LT }\end{array}$ & $\begin{array}{l}\text { Based on organizational rules, } \\
\text { procedures, norms, and } \\
\text { principles }\end{array}$ & $\begin{array}{l}\text { Transactional leadership, } \\
\text { Bureaucratic leadership }\end{array}$ \\
\hline $\begin{array}{l}\text { Relationship or } \\
\text { Transformation } \\
\text { LT }\end{array}$ & $\begin{array}{l}\text { Establishing connections } \\
\text { between managers and } \\
\text { followers }\end{array}$ & $\begin{array}{l}\text { Democratic leadership, Servant } \\
\text { Leadership, Charismatic leadership }\end{array}$ \\
\hline
\end{tabular}

Note: Table based on author's assessments and various sources. 
The leadership theories outlined above are the major theories explaining leadership as a hierarchical phenomenon. This hierarchy can vary from a tight to lose structure depending on the organization's structure, leadership capacity and type, and followers' characteristics. However, these theories ignore lateral leadership, in which creativity and collaboration are critical. Furthermore, these leadership styles also display a hierarchical understanding regarding a tight or loose leadership style. The next section examines lateral leadership across various working environments, leadership characteristics, organizational structures, and followers' qualifications.

\section{LATERAL LEADERSHIP:} PHILOSOPHICAL BACKGROUND

Since the 1970s, there has been a search for new techniques, ideas, and approaches to maximize profits in competitive economic and business life. Lateral leadership is derived from the lateral thinking approach of Edward de Bono in his 1970 book Lateral Thinking. Bono defined lateral thinking as a very different way of logical thinking, closely related to insight, creativity, and humor (Bono, 1970: 1). He divides thinking into two methods. Vertical thinking uses traditional, longestablished logical processes whereas lateral thinking involves disrupting the specific order of thinking to find solutions from other angles and in new ways (Bono, 2014).

An outstanding example of applying lateral thinking is Bono's consultation for Ford Motor Corporation about how to compete more effectively in Europe. To help Ford make its cars more attractive to consumers, Bono approached the problem from a new perspective by asking how Ford could improve the whole driving experience for customers. His answer was always to enable them to park in congested cities. He therefore advised Ford to buy parking lots in all major city centers for the exclusive use of Ford cars (Sloane, 2004: 5758). Through this simple yet very innovative and creative approach, de Bono identified a novel solution that unexpectedly increased Ford's car sales.

Another significant example of creativity and innovation concerns the Swiss brand Swatch. It needed to compete with cheap, good-quality 


\section{Leadership Without Hierarchy and Authority: Lateral Leadership}

Japanese watches, which were driving Swiss brands like Longines, Tissot, and Omega out of business (Sloane, 2004: 5-6). Similarly, whereas there were many cellular phone brands in the early 2000s (e.g. Nokia and Sony), only three companies, Apple, Samsung, and Huawe remain as global top-quality producers. As with the other examples, their success has depended on creativity, innovative ideas, and thinking differently while merging technology with people's desires and pleasures in one machine. Finally, Jeff Bezos, founder of Amazon, the world's largest online seller, has achieved his success by implementing creative and innovative distribution systems. His firm developed a combination of central warehouses with many local or regional warehouses close to customers, thereby enabling customers to receive orders quickly while reducing transportation costs. What these success stories have in common is that the leaders of the companies involved rejected traditional thinking for better ways to make their businesses more effective.

Traditional thinking has been defined as vertical thinking, using conventional approaches and techniques to solve problems. Table 2. summarizes the differences between vertical and lateral thinking approaches along various dimensions.

Table 2. Differences between Vertical Thinking and Lateral Thinking

\begin{tabular}{|l|l|}
\hline \multicolumn{1}{|c|}{ Vertical Thinking } & \multicolumn{1}{c|}{ Lateral Thinking } \\
\hline Selective: choosing among alternatives & Generative: creating new alternatives \\
\hline $\begin{array}{l}\text { Progresses the ideas generated by } \\
\text { lateral thinking }\end{array}$ & Improves the effectiveness of vertical thinking \\
\hline Traditional & $\begin{array}{l}\text { Searching for post-modern approaches } \\
\text { (author's suggestion) }\end{array}$ \\
\hline Needs correction at every step & Does not need correction at every step \\
\hline $\begin{array}{l}\text { Concentrating on and eliminating } \\
\text { irrelevant approaches }\end{array}$ & $\begin{array}{l}\text { Examining different approaches to find the } \\
\text { most promising }\end{array}$ \\
\hline Analytical and sequential & Provocative and can make jumps if necessary \\
\hline Fixed categories, and labels & Categories, etc. not fixed \\
\hline Focusing on most likely approaches & Also searching for least likely approaches \\
\hline Correctness cannot be disregarded & Richness is essential in lateral thinking \\
\hline Finite process & $\begin{array}{l}\text { Probabilistic process: explore chances of an } \\
\text { optimal solution without guaranteeing one }\end{array}$ \\
\hline Direct approach (author's suggestion) & $\begin{array}{l}\text { Also explores indirect approaches for } \\
\text { promising alternatives (author's suggestion) }\end{array}$ \\
\hline
\end{tabular}

Note: Table prepared from de Bono (1970) along with author's suggestions 
Table 2. clearly indicates that lateral thinking is quite different from traditional vertical thinking, which is based on analytical examination and searching for the correct solution or decision. Such thinking requires a sequential approach with correction at every step to eliminate irrelevant alternatives or facts to avoid errors. Vertical thinking focuses on selecting among alternatives based on correctness or truth. Unlike classical or vertical thinking, lateral thinking is a new rhetoric that critically focuses on examining different approaches to generate new ideas and create new alternatives to find the most promising. It therefore also searches for the least likely approaches as they add richness to the decision-making system. This also improves the effectiveness of vertical thinking (Bono, 1970: 8; 34).

In sum, the essential feature of lateral thinking in business is that it abandons traditional approaches, techniques, ideas, etc. in every field and organization in favor of searching for and examining new ones that can enable an organization to become more competitive. Creativity is one cornerstone of lateral thinking: producing new ideas, concepts, and designs. The other key element is innovation: developing and implementing creative ideas. Innovation is not just making new products; it also includes new business processes, fresh ways of making things, radical alliances, and new marketing and business strategies (Sloane, 2003: 7-8). Creativity and innovation are thus linked to each other. The combination of their potential enables lateral thinking to be realized (Bono, 1970: 8). Finally, it should be noted that vertical and lateral thinking are not rivals or antagonistic concepts. On the contrary, they complement one other: lateral thinking makes vertical thinking more effective by proposing more options; vertical thinking improves lateral thinking by utilizing the ideas it creates more systematically (Bono, 1970: 34).

\subsection{Transformation from Lateral Thinking to Lateral Leadership}

Since the emergence of lateral thinking, the focus has shifted to lateral leadership in response to the growing complexity and interdependence of world demands (Yip et al., 2011: 2). "In an era of globalization and heightened competition, organizations and their employees operate in an environment of constant change" (Rob, 2017). Horizontal boundaries are a challenge for leaders. Therefore, classical leadership styles are unlikely to deal with the complex challenges of the globalized world. Conventional leaders manage vertically by 


\section{Leadership Without Hierarchy and Authority: Lateral Leadership}

working upwards and downwards. However, in today's interconnected world, leaders must work efficiently across functions and locations, and with different stakeholders. Worldwide competition, varying demographics, and growing crossorganizational interactions are drastically altering business dynamics (Yip et. al., 2011: 2).

"One significant shift in today's knowledge economy is the transformation of organizations from rigid hierarchical structures to networked structures involving flows of people, information, and resources across boundaries. This has increasingly blurred the traditional boundaries separating employees, contractors, consultants, partners, suppliers, and customers" (Rob, 2017). To cope with these new dynamics and working environments, a new, effective leadership thinking approach is required.

Since the mid-1970s, there has been growing criticism of the role of leadership in organizations, business life, and commercial activities. In 1977, for example, Pfeffer (1977) critically analyzed leadership in management in the "Ambiguity of Leadership". He argued that the definition and measurement of leadership remained unclear. Specifically, it was hard to prove a causal link between leadership and organizational performance based on leadership selection processes. Furthermore, he claimed that attributing such a causal relationship to one individual rather than a set of complex inter-relationships was overly simplistic (Lakomski, 2005: 4).

Today's world requires a different style of leadership that understands the challenges and implications of an interconnected globalized world, and comprehends new leadership features, and the transformation of organizations from rigid hierarchies to networked structures. Lateral leadership appears to be best placed to cope with this new business context. The next section analyzes this kind of leadership in detail.

\subsection{Comparison of Conventional and Lateral leadership}

In any organization, managers and leaders try their best to make their business competitive and enhance its capacity to achieve customer satisfaction. Vertical thinking is a classical approach based on 
analytical and empirical thinking that searches for the best option within established rules and principles. Within this system, the leader's capacity is generally restricted by vertical boundaries and organizational rules while well-defined processes can limit the exercise of leaders' free will. Such leaders exhibit goal-oriented, decisiveness, which is well suited to a structured environment, such as a mature corporation, government department, or military unit (Sloane, 2003: 6). Such leaders are defined as classical or conventional leaders.

Traditional conceptions of leadership have focused on the leader being in a position of authority. "This authority implies that leaders have control over the other party or parties, and that it is the leader's responsibility to develop ideas and drive them down through the organization to achieve successful implementation" (Rob, 2017).

Vertical management structures and leadership can still improve a company's overall performance. However, the changing business environment, technological development, interconnected economic activities, mergers, varying employee characteristics, and easy access to information have altered management structures and roles, and required the development of new leadership styles to respond to these challenges. The transformation of organizations from inflexible hierarchical configurations to networked structures also necessitates new leadership models.

In contrast, lateral leadership uses more appropriate means of achieving corporate goals, most crucially innovativeness and creativity. Lateral leadership encourages and authorizes employees to take inventive and risk-taking approaches to grasp new opportunities. Lateral leadership seeks to eliminate hierarchal chains because they severely restrict the free will of both leaders and followers to exploit new opportunities. 


\section{Leadership Without Hierarchy and Authority: Lateral Leadership}

Table 3. Comparison of Conventional and Lateral leadership

\begin{tabular}{|l|l|}
\hline \multicolumn{1}{|c|}{ Conventional leadership } & \multicolumn{1}{c|}{ Lateral leadership } \\
\hline Based on vertical thinking & Based on lateral thinking \\
\hline $\begin{array}{l}\text { Leader's capacity restricted by vertical } \\
\text { boundaries, organizational rules, and well- } \\
\text { defined procedures }\end{array}$ & $\begin{array}{l}\text { Leaders freer from boundaries, rules, and } \\
\text { procedures }\end{array}$ \\
\hline $\begin{array}{l}\text { Utilizing conventional ways to improve } \\
\text { effectiveness and efficiency }\end{array}$ & $\begin{array}{l}\text { Utilizing new means; willingness to } \\
\text { change rules, partners, or approaches if } \\
\text { necessary }\end{array}$ \\
\hline $\begin{array}{l}\text { Having a robust sense of path and } \\
\text { determination }\end{array}$ & Having a vision of inspiring followers \\
\hline $\begin{array}{l}\text { Seeking higher productivity, quicker } \\
\text { development, more aggressive sales and } \\
\text { marketing }\end{array}$ & $\begin{array}{l}\text { Seeking new methods, new approaches to } \\
\text { customers and partnerships }\end{array}$ \\
\hline Seeing followers as subordinates & Seeing followers as colleagues \\
\hline $\begin{array}{l}\text { Being decisive, often without prior } \\
\text { consultation }\end{array}$ & $\begin{array}{l}\text { Soliciting followers' contributions before } \\
\text { making decisions }\end{array}$ \\
\hline $\begin{array}{l}\text { Strongly emphasizing analytical, critical, } \\
\text { logical thinking }\end{array}$ & $\begin{array}{l}\text { Strongly emphasizing lateral thinking but } \\
\text { without disregarding other approaches }\end{array}$ \\
\hline Focus on actions and results & $\begin{array}{l}\text { Focus on direction and innovation to } \\
\text { achieve results }\end{array}$ \\
\hline $\begin{array}{l}\text { Instructing followers } \\
\text { Discouraging dissent }\end{array}$ & $\begin{array}{l}\text { Empowering followers } \\
\text { Encouraging constructive dissent }\end{array}$ \\
\hline Rewarding performance and results & Rewarding creativity and risk taking \\
\hline Maintaining strong authority & auts leadership without \\
\hline
\end{tabular}

Note: based on Sloane, 2003: 12-13; 2017: 2-3, and author's suggestions.

As Table 3. shows, conventional and vertical leaders reflect varying working and economic necessities. A conventional leader's freedom of action is restricted by vertical boundaries and organizational rules, so their focus will be on accomplishing organizational goals within these constraints. Conversely, lateral leaders' working boundaries are less restrictive, so they must develop creative and innovative techniques, solutions, and approaches, and change the rules and partners to achieve organizational goals. The major attitudinal difference between them concerns their approach to followers. Conventional leaders treat them as subordinates in accordance with well-defined organizational rules and behave as instructors to prevent mistakes. In contrast, lateral leaders see followers as colleagues due to less restrictive working environments, and aim to empower them, such as by encouraging constructive dissent. Finally, conventional leaders maintain strong authority, focusing on activity, outcomes, and effectiveness, whereas lateral leaders act more as coordinators who aim to inspire the team to

671

IJSI $12 / 2$

Aralık

December

2019 
discover what is new and best (Sloane, 2017). As explained further below, lateral leadership may even evolve towards leadership without authority.

Despite these differences in their decision-making systems and problem-solving approaches, conventional and lateral leadership are not antagonistic. Both desire better management principles to increase organizational efficiency and efficacy to achieve goals. Thus, they can be seen as complementary in covering each other's weaknesses in specific situations. Successful leaders are thus leaders who can appropriately combine traditional and lateral leadership (Sloane, 2017).

\subsection{The evolution of lateral leadership in a globalized world}

The business environment and the scale of economic activities have been enormously affected by global dynamics, the rise of multinational corporations, mergers, and the new structural progress of inter-companies. These developments have forced management to modify its principles and concepts. Most managers well know that reliance on hierarchy is no longer as effective as before (Yip et al., 2011: 12). As discussed above, lateral leadership can better cope with the current demanding management context. It requires developing a strategic mindset about resolving problems and exploring multiple solution paths (Rosen, 2017). Additionally, growing interconnections, assisted by technological developments, have promoted new methods of organizing, such as cross-functional teams, practical workgroups, and cross-sector partnerships. This shift has given rise to a set of mission-critical boundaries that leaders must work across (Yip, et al., 2011). The authority exerted by lateral leaders is less directive and enforcing than that of conventional leadership. Lateral leadership has also undergone some modification in its ruling principles to deal with today's complexities of management. Furthermore, as claimed above, "top-down management is now only partially effective, for instance when employees from different companies work on a common task "(Kuhl et al., 2005: 178). Thus, for contemporary working groups, such as cross-functional teams, practical workgroups, and cross sector partnerships, the new leadership - called lateral eldership - is of utmost importance. That is, lateral leadership is evolving towards leadership without authority, whereby leaders have no direct control over followers to achieve common goals. Instead, such leadership is 


\section{Leadership Without Hierarchy and Authority: Lateral Leadership}

shared, collective, disseminated, and seized temporarily by individuals across a network (Kuhl et al., 2005: 178). Increasingly, organizational hierarchies are becoming less important; instead, companies are focusing more on network-like structures (www.mditraining.com). Furthermore, the traditional pyramidal organizational structure is becoming obsolete in business life. In today's business environment, there is greater need for improvization (Fursberger, 2018).

To understand lateral leadership, it is also necessary to consider changes in the expectations of younger generations. Generation $Y$ (those born between 1981 and 1999) generally reject hierarchy and call for cooperation while Generation Z (born after 2000) has grown up in a technologically connected world. Such advances, including the explosion of knowledge and wider availability of information, have the acceptance of hierarchical leadership in organizations (Fursberger, 2018). These new generations can hardly be forced to work within such hierarchical restrictions.

Nowadays, followers increasingly find solutions themselves, even to complex problems, as not all information reaches the highest management levels. The senior leadership may be unable to process information sufficiently fast, even if they receive it in time. Furthermore, for project and steering groups, the chairperson can only behave as a coordinator while rarely being able to resolve conflicts by utilizing their authority as chair (Kuhl et al., 2005: 177-178).

This new context requires collaborative, creative, and innovative approaches, in which all participants are treated as equal. Lateral leadership can easily respond to these challenges as its collaborative and creative features enable all partners to be part of the project or task. "Lateral leadership does not manifest itself through vertical influence but through horizontal, cooperative relationships. Lateral leadership follows different principles to classical hierarchical leadership, specifically a goal oriented, social, interpersonal, and behavioral influence "(Kuhl et al., 2005: 178). Through communication processes, lateral leaders enable shared tasks to be completed (Kuhl et al., 2005).

Additionally, lateral leaders construct relationships with individuals across networks to facilitate opportunities for potential allies to 
explore alternative resolutions, options, or decisions that might improve the company's overall efficacy. They are therefore open to new ideas and differing values, attitudes, and assumptions (www.central.knowledge.scot.nhs.uk). A key element of lateral leadership is a commitment to achieving common goals using effective communication. As a communicator, the lateral leader develops and promotes relationships leading to win-win situations (www.mditraining.com).

Lateral leadership may encounter challenges as hierarchical authority disappears. For example, labor in an organization is divided between different functional or production units (Kuhl et al., 2005: 179), so one office can generally hardly manage all decisions.

The agile teams of the $21^{\text {st }}$ century must be flexible, loosely structured, and self-organizing to respond to the emerging challenges in business and economic life. This organizational transformation has however created a crisis in leadership. A new challenge concerns the question of who is responsible when autonomous teams work side by side together. Influencing others without formal authority is thus a necessary skill for both small businesses and large companies.

Lateral leadership operates at the intersection of harmony and empathy. Yet, although compliance and empathy are equally important, they must be prioritized differently depending on the working environment (Tim, 2018). Therefore, central authority may sometimes be required. Additionally, all individuals in an organization want their views to be accepted in discussions, bearing in mind that opinions are increasingly entrenched in myth and dogma (Kuhl et al., 2005: 179). Loss of leadership authority during crises can thus create problems.

Because these factors may hinder the implementation of lateral leadership, the following ideas are essential to facilitate implementation of lateral leadership in such cases. The first is to create a common conceptual framework to replace hard views. A basic element of lateral leadership is to develop a commitment to achieving shared goals (www.mdi-training.com). This shared understanding depends on collaborative efforts to enable all sides to agree on the issue and avoid disagreement. While creating shared understanding, the object is not to create an overarching perspective 


\section{Leadership Without Hierarchy and Authority: Lateral Leadership}

(Kuhl et al., 2005: 179). The second suggestion is to form viable connections between the participants' divergent interests, which this entails a power play. The lateral leader as a communicator develops and fosters relationships that lead to win win-situations (www.mditraining.com). The third idea is to create trust. The partners should be able to make concessions in hopes of receiving a later return on their investment in the project (Kuhl et al., 2005: 178). Therefore, project managers, coordinators, team leaders, and facilitators must all practice lateral leadership. "They must produce cooperation between employees from different areas of a firm who generally only cooperate on a temporary basis" project (Kuhl et al., 2005: 179).

\section{CONCLUSION}

This paper analyzed leadership as the major driving force for success or failure in any organization across all fields. The evolution of leaderships and styles has varied according to development level, technological progress, employee knowledge capacity, organizational structure, economic development, and leaders' own features. Historical developments indicate that leadership and management have continuously evolved from tough leadership types and styles towards more moderate forms. Traditional leadership styles require hierarchical processes primarily characterized by exerting power. Recent studies have promoted a new theoretical approach toward leadership that disregards hierarchy to focus on insight, collaboration, coordination, and creativity to achieve organizational goals.

The philosophical background of traditional leadership styles is characterized by vertical rhetoric based on an analytical examination and search for correct solutions or decisions. In contrast, lateral thinking is a new rhetoric focused on exploring different approaches until promising ones are discovered. Its essential characteristics are generating new ideas and creating new alternatives to find the most promising alternative.

Conventional or traditional leadership thus relies on vertical thinking, which reflects earlier economic phases of industrialization and mass production that characterize modernity. In contrast, lateral leadership is based on lateral thinking and a new leadership style to deal with the challenges of post-modernity, characterized by the growing 
complexity and global interdependence created by multi-national corporations, mergers, and the new structural progresses of intercompanies. Overall, lateral leadership involves developing a strategic mindset about problems while exploring multiple solution paths (Rosen, 2017). Hierarchy is no longer as important as before. Instead, growing interconnections, assisted by technological progress, "have led to new methods of organizing, such as cross-functional teams, practical workgroups, and cross-sector partnerships" (Yip, et al., 2011: 12). This new structure can best be managed by lateral leaders who inspire and coach their teams to become a truly creative force and thereby develop innovative solutions (Sloane, 2006: 9). The basic

Lateral leadership is quite a new development that is appropriate for the changing working environment, leadership characteristics, organizational structure, and followers' qualifications. This leadership style best matches group studies, ad hoc meetings, or lateral networking structures in organizations in which conventional/ traditional leadership is ineffective or function is minimal.

In sum, lateral leadership has evolved based on lateral thinking as new approach to business, political, economic, and cultural life. Its evolution has shifted to more specific areas where creativity and innovation, as well as collaboration and coordination, are crucial, where hierarchical authority is ignored, and where opportunities for new ideas and beliefs are welcome. 


\section{Leadership Without Hierarchy and Authority: Lateral Leadership}

\section{REFERENCES}

Amanchukwu, Rose Ngozi; Stanley, Gloria Jones and Ololube, Nwachukwu Prince (2015). “A Review of Leadership Theories, Principles and Styles and Their Relevance to Educational Management". Management, 5(1), 6-14.

Avolio, Bruce J. (2007). "Promoting More Integrative Strategies for Leadership Theory Building". American Psychologist, 62, 25-33.

Bono, Edward (2014). Lateral Thinking. London: Vermilion Press.

Bono, Edward (1990). Lateral Thinking. Reprinted in Penguin Books.

Bono, Edward de (1970). Lateral Thinking. Penguin Books.

Cherry, Kendra (2012). Leadership Theories - 8 Major Leadership Theories. http://psychology.about.com/od/leadership/p/leadtheories.htm

Dierendonck, Dirk van; Patterson, Kathleen (2010). “Servant Leadership: An Introduction", Dierendonck, Dirk van; Patterson, Kathleen (Eds.), Servant Leadership Developments in Theory and Research, UK/ USA: Plagrave-Mcmillian.

Fursberger, Gunther and Inehichen, Tanja (2018). How to Win Commitment as Lateral Leader. Germany: Haufer.

Herbig, Tim (2018). Lateral Leadership: A Practical Guide for Agile Product Managers. USA: Sense and Response Press.

Kuhl, Stefan (2017). Lateral Leading A Very Brief Introduction to Power, Understanding and Trust. Organizational Dialogue Press.

Kuhl, Stefan; Schnelle, Thomas and Tillmann, Franz-Josef (2005). "Lateral Leadership: An Organizational Approach to Change". Journal of Change Management, 5(2), 177-189.

Lakomski, Gabriele (2005). Managing without Leadership. Melbourne, Australia: Elsevier.

Llyod, Nancy (2013). Ouantum Leadership. Bloomington: Balboa Press.

Rosen, Rob (2017). "Lateral Leadership: A New Approach to Leadership in Today's Evolving Corporate Environment", http://www.cmpartners.com/negotiatorspause/lateral-leadership-new-approach-leadership-todays-evolvingcorporate-environment/, (Access: 28 July 2019).

Shah, Shivanee (2018). "Secondary Research - The Basics of Narrative Reviews, Systematic Reviews, And Meta-Analysis". https :/ / doi.org/10.34193/EI-A-1066, (Access: 19 November 2019).

Sloane, Paul (2003). The Leader's Guide to Lateral Thinking Skills. GB and USA: Kogan Page Limited. 


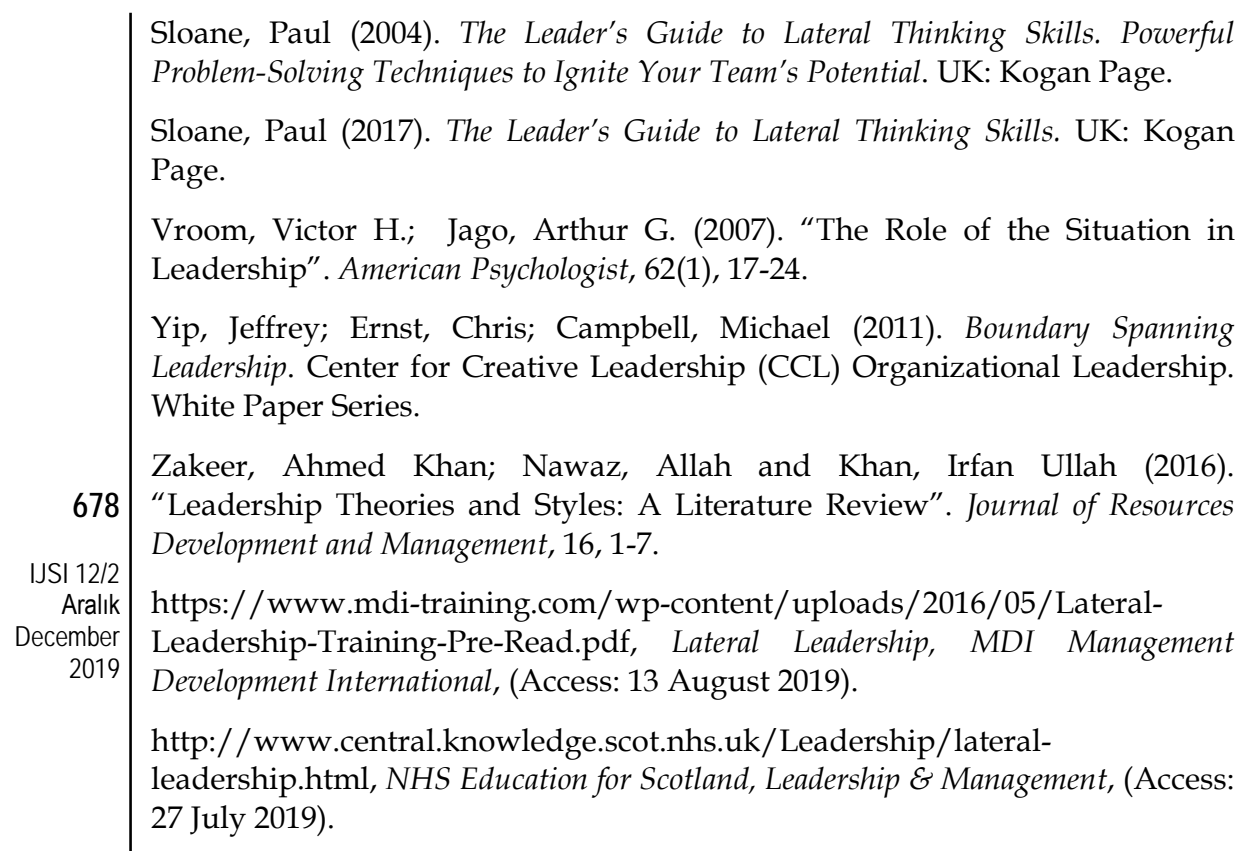




\section{Leadership Without Hierarchy and Authority: Lateral Leadership}

\section{ÖZET}

Bilim insanlarının liderliğin toplumdaki, politikadaki ve iş dünyasındaki rolüne dair süre gelen şiddetli tartışmaları söz konusudur. Bu konu, sosyal bilim alanı genişledikçe, sadece yönetim alanı araştırmacılarından değil, aynı zamanda psikologlardan, sosyologlardan, filozoflardan da yoğun ilgi görmüştür. Bu alanlardaki araştırmacılar liderliğin, işletmelerin, siyasi organizasyonların ve sosyal hareketlerin başarısında veya başarısızlığında çok önemli bir rol oynadığı hususunda hem fikirdir. Liderlik ve tarzı, işletme faaliyetlerini büyük ölçüde etkileyebileceği için, işletme liderlerinin organizasyon içinde ve dışındaki etkileşimleri mercek altındadır.

Liderlik tarzları, liderlerin diğerlerini harekete geçirme yetkisine sahip olması nedeniyle çeşitli bakış açılarından farklılık gösterebilir. Liderlerin takipçileri etkileme gücüne sahip olduğu aşikardır. Lidere verilen bu gücün dayanağı yasal, içsel- doğal, yaşa dayalı tecrübe veya geleneksellik, bürokratik veya otokratik faktörler olabilir. Bu güç kaynakları, kendi liderlik tarzlarını yaratabilir.

Geleneksel olarak ifade edilen liderlik tarzları, esas olarak güç ile karakterize edilen hiyerarşik süreçleri gerektirir. Ancak, son çalışmalar, örgütsel amaçlara ulaşmak için tüm paydaşlarla, özellikle çalışanlarla iç görü, iş birliği, eşgüdüm ve yaratıcılığa odaklanan alt yaklaşımın yerini alan liderlik tarzına yönelik yeni bir teorik yaklaşım geliştirmiştir. Bu liderlik tarzı "lateral liderlik" tir ve hiyerarşik bir çalışma atmosferinden kaçınır.

Bu makale lateral liderlik ele alınmıştır. Lateral liderliği gün yüzüne çıkarmak için entelektüel arka planı hazırlanmış, Liderlik kavramı tanımlanmış, liderlik ve liderlik tarzlarının teorik yönleri ele alınmıştır. Daha sonra lateral liderliğin nasıl kavramsallaştırılabileceği ve pratikteki diğer liderlik tarzlarından nasıl farklılaştığı açıklanmaya çalışılmıştır.

Makale, nispeten yeni bir yaklaşım olan yanal liderliğin, çalışma ortamlarını, liderlik özelliklerini, organizasyonel yapıları ve takipçilerin niteliklerini değiştirmek için uygun bir liderlik tarzı olduğunu öne sürmektedir. Bu liderlik stilinin, geleneksel liderliğin etkisiz olduğu organizasyonlardaki grup çalışmaları, geçici toplantılar veya lateral ağların oluşturduğu yapılar için uygundur. Lateral liderliği araştırmak ve evrimine 1şık tutmak için derlenen bu çalışma nitel bir yaklaşım benimsemiştir.

Zaman içinde, Liderlik tarzları evirilmiş; teknolojik ilerleme, çalışanların bilgi kapasitesi, organizasyonel yap1, ekonomik gelişme ve liderlerin kendi özelliklerine göre değişim göstermiştir. Tarihsel gelişmeler, liderliğin ve yönetimin, zorlu liderlik türlerinden ve tarzlarından daha ılımlı biçimlere 


\section{R. Dilek KOÇAK}

doğru sürekli geliştiğini göstermektedir. Geleneksel liderlik tarzları, öncelikle güç uygulamakla karakterize hiyerarşik süreçleri gerektirir. Son çalışmalar, örgütsel hedeflere ulaşmak için iç görü, iş birliği, koordinasyon ve yaratıcılığa odaklanmak üzere hiyerarşiyi göz ardı eden liderliğe yönelik yeni bir teorik yaklaşım geliştirmiştir.

Geleneksel liderlik tarzlarının felsefi arka planı, analitik incelemeye ve doğru çözüm veya kararları aramaya dayanan dikey söylemlerle karakterize edilir. Geleneksel liderlik, sanayileşmenin daha erken ekonomik evrelerini ve modernliği karakterize eden ve kitlesel üretimi yansıtan dikey düşünceye dayanır. Buna karşıllk, lateral düşünme, gelecek vaat edenlerin keşfedilmesine kadar farklı yaklaşımları keşfetmeye odaklanan yeni bir söylemdir. Temel özelliği "en umut verici alternatifi bulmak için yeni fikirler üretmek ve yeni alternatifler oluşturmaktır". Lateral liderlik, lateral düşünceye ve post-modernitenin zorluklarıyla başa çıkmak için yeni bir liderlik tarzına dayanmaktadır; işletmeler. Genel olarak, lateral liderlik birden fazla çözüm yolunu keşfederken problemler hakkında stratejik bir zihniyet geliştirmeyi hedefler. Hiyerarşinin artık eskisi kadar önemli olmadığı günümüz dijital çağında, teknolojik ilerlemeyle desteklenen, artan bağlantılar, işlevler arası ekipler, pratik çalışma grupları ve sektörler arası ortaklıklar gibi yeni organizasyon yöntemleri ortaya çıkmıştır. Bu yeni yapı, ancak ve ancak takımlarına gerçekten yaratıcı bir güç olma konusunda ilham veren, koçluk yapan ve böylece yenilikçi çözümler geliştiren lateral liderler tarafından yönetilebilir. 